\title{
PELATIHAN PENGELOLAAN DESA WISATA UNTUK PENINGKATAN SUMBER DAYA MANUSIA DI KABUPATEN BUTON
}

\author{
Rachmat Astiana ${ }^{1}$, Lia Afriza ${ }^{2}$, Wildan Rizky Rahadian ${ }^{3}$ \\ ${ }^{1,2)}$ STIE Pariwisata Yapari, \\ ${ }^{3)}$ Sekolah Tinggi Pariwisata Bogor \\ e-mail: rachmatastiana@gmail.com¹, lia.afriza@gmail.com²,wildanrizkyrahadian@gmail.com ${ }^{3}$
}

\begin{abstract}
Abstrak
Kegiatan pengelolaan desa wisata bertujuan membantu menyiapkan masyarakat desa untuk meningkatkan perekonomian mereka melalui kegiatan pariwisata serta menyediakan wadah pengabdian masyarakat bagi para akademisi yang terlibat. Program diadakan oleh Pemerintah daerah dengan memberikan Training kepada para masyarakat (pokdarwis, aparat desa, tokoh masyrakat) selama 3 (tiga) hari dan diikuti oleh 42 (empat puluh dua) peserta. Kegiatan ini berfungsi sebagai tempat upgrading knowledge dan penyetaraan materi pelatihan yang akan digunakan di desa wisata. Pada sesi ini materi yang disampaikan berjudul Pengelolaan Desa Wisata. Pelatihan ini menggunakan metode ceramah, tanya jawab (diskusi) dan evaluasi menggunakan kuis. Dari survey yang dilakukan kepada para peserta pelatihan terungkap bahwa seluruh peserta menganggap materi ini menarik dan kekinian, dibutuhkan dan mudah dipahami serta bisa diterapkan pada desa wisata yang didampinginya. Sebagai saran dan masukan dari peserta, materi tersebut hendaknya diikuti juga dengan praktik lapangan yang langsung dilakukan di desa wisata.
\end{abstract}

Kata Kunci : Desa Wisata, Daya Tarik, Atraksi

\begin{abstract}
Village tourism management activities aim to help prepare rural communities to improve their economy through tourism activities and providing a forum for community service for the academics involved. The program is held by the local government by providing training to the community (pokdarwis, village officials, community leaders) for 3 (three) days and attended by 42 (forty-two) participants. This activity serves as a place for upgrading knowledge and equalizing training materials that will be used in tourist villages. In this session, the material presented was entitled Tourism Village Management. This training uses the lecture method, question and answer (discussion) and evaluation using a quiz. From the survey conducted to the training participants, it was revealed that all participants found this material interesting and up-to-date, needed and easy to understand and could be applied to the tourist villages they accompany. As suggestions and input from participants, these materials should also be followed by field practice which is directly carried out in tourist villages.
\end{abstract}

Keywords: Tourism village, Attraction, Attraction

\section{PENDAHULUAN}

Kabupaten Buton merupakan salah satu daerah tingkat II yang terdapat di Provinsi Sulawesi Tenggara terdiri dari 7 Kecamatan. Kabupaten Buton terletak di Pulau Buton dengan ibukotanya yaitu Pasarwajo, dimana kabupaten ini terkenal dengan daerah penghasil aspal terbaik dan terbesar di dunia. Pada awalnya Kabupaten Buton adalah bekas kerajaan Kesultanan Buton yang meliputi sebagian wilayah pulau Buton, sebagian wilayah Pulau Muna sedikit pulau Sulawesi serta pulau pulau yang ada di selatan Pulau Buton dengan ibukotanya berada di BauBau. Namun saat ini telah terjadi pemekaran daerah menjadi enam wilayah Kota/Kabupaten.

Kabupaten Buton memiliki potensi alam yang lengkap terdiri dari pegunungan, hutan, sungai, gua, laut dan pantai. Dengan kekayaan alam utama yaitu tambang aspal dilengkapi dengan sektor perikanan yang melimpah serta sektor perkebunan jambu mete yang cukup besar. Terdapat banyak pantai yang indah 
yang memiliki aktivitas diving, snorkeling yang tidak kalah menarik dengan Wakatobi. Selain itu Kabupaten Buton juga memiliki kawasan hutan lindung dan kawasan konservasi hutan yang telah ditetapkan sebagai "paru-paru dunia" yaitu Hutan Lambusango dimana terdapat beberapa hewan langka seperti Anoa dan tarsius. Potensi budaya yang dimiliki buton yakni terdapatnya banyak upacara adat dan pesta kampung yang sarat dengan kekentalan budayanya. Selain itu banyak peninggalan kesultanan Buton yang masih eksis sampai saat ini, berbagai macam benteng, makam raja, prasasti dan peninggalan lainnya. Terdapat pula kerajinan tenun kain khas buton serta anyaman yang menjadi tambahan potensi melalui industri kreatif. (www.butonkab.go.id)

Desa di Kabupaten Buton miliki potensi daya tarik yang perlu dikelola dengan baik oleh masyarakat desa sehingga dapat dinikmati manfaat oleh masyarakat desa. Salah satu upaya pemerintah yaitu mengemas desa menjadi desa wisata. Untuk mengembangkan desa wisata tentunya perlu Sumberdaya manusia yang handal sehingga desa wisata yang menjadi salah satu solusi dalam pemberdayaan masyarakat (Community Based Tourism) yang imbasnya akan meningkatkan perekonomian masyarakat desa. hal ini sejalan dalam pengembangan kepariwisataan yang dikemukakan oleh UNWTO yaitu terdiri dari; Pro Job, Pro Growth, Pro Poor, Pro Environment. Atas dasar hal tersebut pemerintah daerah melalui Dinas Pariwisata Kabupaten Buton melakukan pelatihan pengelolaan desa wisata pada tanggal 21-23 Juni 2021 bertempat di Aula Hotel Buton Raya Pasarwajo. Para trainer pelatihan tersebut yakni Lia Afriza, SE.,MM.; Rachmat Astiana, S.Par., MM.Par., dan Wildan Rizky Rahadian, S.Par., MM.Par.; terdiri dari 42 peserta yang tersebar dari seluruh kecamatan di Buton. Materi pada pelatihan ini yakni penyiapan sumberdaya manusia yang ada di desa dalam rangka peningkatan kapasitas masyarakat dalam mengelola desa wisata.

Desa Wisata merupakan suatu kawasan pedesaan yang menawarkan keseluruhan suasana yang mencerminkan keaslian pedesaan baik dari kehidupan sosial ekonomi, sosial budaya, adat istiadat, keseharian, memiliki arsitektur bangunan dari struktur tata ruang desa yang khas atau kegiatan perekonomian yang unik dan menarik serta mempunyai potensi untuk dikembangkannya berbagai komponen kepariwisataan, misalnya; atraksi, akomodasi, makanan-minuman, cinderamata dan kebutuhan wisata lainnya. (Soemarno, 2010).

Desa Wisata dibentuk untuk memberdayakan masyarakat agar dapat berperan sebagai pelaku langsung dalam upaya meningkatkan kesiapan dan kepedulian dalam menyikapi potensi pariwisata atau lokasi daya tarik wisata di wilayah mereka agar dapat berperan sebagai tuan rumah yang baik bagi para wisatawan yang berkunjung, serta memiliki kesadaran akan peluang dan kesiapan menangkap manfaat yang dapat dikembangkan dari kegiatan pariwisata untuk meningkatkan kesejahteraan ekonomi masyarakat.

Suatu kawasan dikatakan dapat menjadi desa wisata harus memperhatikan faktor-faktor sebagai berikut (Syamsu dalam Prakoso, 2008):

1. Faktor kelangkaan adalah sifat dari atraksi wisata yang tidak bias dijumpai atau langka di tempat lain.

2. Faktor kealamiahan adalah sifat atraksi wisata yang belum pernah mengalami perubahan akibat campur tangan manusia.

3. Keunikan, yakni sifat atraksi wisata yang memiliki keunggulan komparatif disbanding objek wisata lain.

4. Faktor pemberdayaan masyarakat yang mampu menghimbau agar masyarakat ikut serta dan diberdayakan dalam pengelolaan objek wisata di daerahnya.

Adapun Kriteria pengembangan desa wisata adalah adanya 4A +1 C yaitu :

1. Memiliki Attraction/Atraksi wisata unggulan

2. Memiliki Amenities/Fasilitas Pendukung

3. Memiliki Accessibility/Sarana-Prasarana yang memadai

4. Memiliki Ancillaries/Layanan tambahan termasuk kelembagaan

5. Memiliki Community Involvement/Keterlibatan Masyarakat 
Langkah - langkah pengembangan desa wisata dapat dilakukan dengan beberapa cara, antara lain :

1. Memetakan wilayah dengan mengidentifikasi potensi alam, sosial, budaya yang ada di desa

2. Menata wajah desa dengan memperbaiki fasilitas umum, pemukiman, serta yang lebih penting membaskan wilayah kita dari sampah terutama plastik.

3. Menyiapkan Sumber Daya Manusia, Kelembagaan, dan Jaringan

a. Membuat aturan atau rambu-rambu pengelolaan desa wisata

b. Membentuk badan pengelola

c. Merancang program kerja (pendek, menengah dan panjang)

d. Mengembangkan jaringan dan kerja sama.

Pengembangan pariwisata harus memenuhi empat kriteria agar objek tersebut diminati pengunjung yaitu: 1) Something to see adalah objek wisata tersebut harus mempunyai sesuatu yang bisa dilihat atau dijadikan objek tontonan oleh pengunjung wisata; 2) Something to do adalah agar wisatawan yang melihat objek wisata di sana bisa melakukan sesuatu yang berguna untuk memberikan perasaan senang dan bahagia, rileks berupa fasilitas rekreasi baik itu arena bermain ataupun tempat makan khas dari tempat tersebut hingga mampu membuat wisatawan lebih betah untuk tinggal di sana; 3) Something to buy adalah fasilitas untuk wisatawan berbelanja yang pada umumnya adalah ciri khas atau icon dari daerah tersebut, hingga bisa dijadikan oleh-oleh. Agar suatu objek wisata dijadikan sebagai salah satu objek wisata yang menarik, maka faktor yang sangat menunjang adalah kelengkapan dari saran dan prasaran objek tersebut; 4) Something to learn adalah objek wisata juga harus memberikan nilai edukasi (Yoeti, 2010).

Empat kriteria pengembangan desa wisata inilah yang kemudian oleh pemuda desa harus mampu dikemas menjadi sebuah nilai yang mampu menarik calon wisatawan, ataupun calon patner yang akan mengembangkan desa wisata menjadi satu kebutuhan pariwisata yang akan meningkatkan ekonomi desa tersebut. Untuk itu dibutuhkan kemampuan dalam mencitrakan pesan khusus dari potensi lokal yang dimiliki. Dan untuk itu perlu adanya pelatihan atau pendampingan guna meningkatkan sumberdaya yang ada di desa sesuai dengan bakat yang dimiliki dari masing masing pemuda atau masyarakat desa yang ingin berperan dalam pengembangan desa wisata tersebut. Peran masyarakat, khususnya kaum muda, sangatlah besar dalam kemajuan sebuah desa wisata (Busaini et al., 2020; Naibaho \& Lubis, 2016; Prabawati, 2019).

Tujuan utama dari kegiatan ini adalah supaya desa wisata dapat meningkatkan peringkatnya menjadi desa mandiri yang diharapkan mensejahterakan penduduknya yang dalam prosesnya juga dapat menjadi wadah bagi akademisi dalam melakukan pengabdian masyarakat yang merupakan salah satu pilar dalam tri dharma perguruan tinggi.

\section{METODE}

Para peserta yang mengikuti kegiatan ini adalah warga desa wisata di wilayah kabupaten Buton, terdiri dari 42 orang peserta. Kegiatan dilakukan melalui tatap muka secara langsung dan dilengkapi dengan kegiatan latihan asesmen lapangan di desa wisata. Secara keseluruhan penyampaian dilakukan dengan beberap metode sebagai berikut :

1. Metode Sosialisasi : Disini disampaikan mengenai beberapa pengertian serta persyaratan menjadi desa wisata. Sadar wisata dan sapta pesona, kelembagaan pengembangan produk dan pengelolaan masa pandemi.

2. Metode Tutorial : Para trainer menampilkan beberapa contoh video tentang keunikan dan pesona yang dimiliki desa wisata serta gambar-gambar terkait yang dapat memacu peserta untuk menumbuhkan kreatifitas dan memberikan gambaran kepada peserta untuk mengembangkan desa wisatanya.

3. Metode diskusi : para peserta melakukan Tanya jawab untuk memperdalam pemahaman dalam pengelolaan desa wisata serta membahas beberapa pengalaman yang pernah terjadi dilapangan.

4. Metode evaluasi : pengukuran sampai dimana pemahaman atas materi yang disampaikan serta memberi masukan dan saran untuk kegiatan pelatihan selanjutnya dimasa depan. 
5. Metode Asesmen lapangan : para peserta melakukan kegiatan penilaian langsung di lapangan secara sederhana terkait desa wisata. (Herawati et al.,2020)

\section{HASIL DAN PEMBAHASAN}

Materi pengelolaan desa wisata merupakan materi yang menarik bagi peserta, terlebih dengan pelatihan ini membuka wawasan peserta bagaimana mengelola desa wisata dengan baik yakni mendorong keterlibatan seluruh masyarakat sehingga dapat meningkatkan kesejahteraan masyarakat desa sehingga dapat memberikan dampak yang lebih baik bagi pembangunan desa. Para peserta sangat antusias dalam mengikuti kegiatan pelatihan tersebut, sekalipun sebagian besar peserta bukan berlatar belakang pendidikan tinggi khususnya bidang pariwisata namun memiliki kemauan tinggi dalam mengembangkan daerahnya. Oleh karena itu penyampaian materi dilakukan secara runut dilengkapi dengan contoh-contoh dalam keseharian, dan kesempatan yang diberikan untuk melakukan diskusi dan tanya jawab oleh pemateri (Djamarah \& Zein, 2006), sehingga mampu memberikan gambaran yang jelas kepada para peserta.

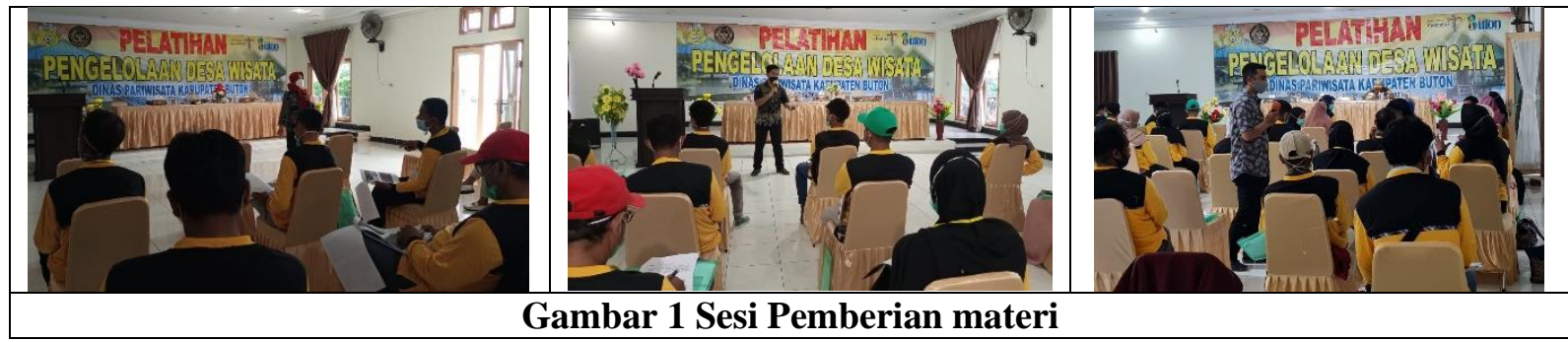

Para peserta dibuka wawasannya terkait sadar wisata dengan menerapkan 7 (tujuh) unsur wisata yakni Sapta pesona sebagai dasar pengembangan wisata. Lalu diberi penjelasan mengenai persyaratan desa wisata sesuai standar nasional dan ASEAN CBT, Kelembagaan pengelola desa wisata, Pengembangan dan pengelolaan produk pariwisata berbasis masyarakat serta pengelolaan desa wisata dimasa penanganan Covid 19. Selain itu peserta juga mendapatkan materi terkait bagiamana memasarkan desa wisata serta bagaimana menangani konflik yang terjadi.

Setelah pemberian materi serta tahapan diskusi dilakukan, peserta diminta untuk menjawab survey untuk dapat menilai terkait materi pelatihan, sarana pelatihan serta penilaian terkait penyampaian oleh narasumber. Untuk materi pelatihan peserta diberi pertanyaan terkait hal berikut :

1. Kesesuain materi

2. Kecukupan materi

3. Sistematika

4. Kejelasan materi

Dari keempat indikator tersebut maka didapatkanlah data terkait penilanan materi pelatihan menggunakan skala 1-5 dimana : nilai 1 diartikan tidak baik, nilai 2 berarti kurang baik, nilai 3 berarti cukup, nilai 4 berarti baik dan nilai 5 berarti sangat baik.

Hasil survey tentang materi pelatihan sebagai berikut :

Tabel 1 Penilaian Materi Pelatihan

\begin{tabular}{|l|c|c|c|c|c|c|c|}
\hline \multirow{2}{*}{\begin{tabular}{|}
\multirow{2}{*}{ Indikator } \\
\cline { 2 - 6 }
\end{tabular}} & $\mathbf{1}$ & $\mathbf{2}$ & $\mathbf{3}$ & $\mathbf{4}$ & $\mathbf{5}$ & \multirow{2}{*}{ Total } & $\begin{array}{c}\text { Rata } \\
\text { Rata }\end{array}$ \\
\hline Kesesuaian materi & 0 & 0 & 6 & 11 & 23 & 177 & 4.4 \\
\hline kecukupan materi & 1 & 0 & 5 & 19 & 15 & 167 & 4.2 \\
\hline Sistematika & 1 & 0 & 7 & 17 & 15 & 165 & 4.1 \\
\hline Kejelasan materi & 1 & 3 & 5 & 8 & 23 & 169 & 4.2 \\
\hline \multicolumn{7}{|c|}{ Rata-Rata Total } \\
\hline
\end{tabular}




\section{Sumber : data olahan penulis}

Dari tabel tersebut dapat disimpulkan bahwa penilaian mengenai materi pelatihan dapat dikatakan baik dengan rata-rata poin 4.2 dengan perincian kesesuainan materi dengan kebutuhan para peserta mendapat poin tertinggi yakni 177 dengan rata-rata nilai sebesar 4.4; untuk kecukupan materi serta kejelasan materi mendapat nilai rata-rata sama yakni 4.2 dengan total nilai yang tidak begitu jauh; sedangkan sistematika mendapat total nilai 165 dengan nilai rata-rata sebesar 4.1. Peserta menyatakan bahwa materi yang diberikan sudah sesuai dengan kebutuhan, dapat dengan mudah mendapat kejelasan serta materi yang diberikan sudah berurut dan terkait satu sama lainnya.

Hasil Survey tentang sarana pelatihan dengan indikator sebagai berikut :

1. Kenyamanan ruangan

2. Kualitas media

3. Ketersediaan materi pelatihan

4. Ketersediaan pelatihan lainnya

5. Ketersediaan sarana pembelajaran

Dari kelima indikator tersebut maka didapatkanlah data sebagai berikut :

Tabel 2 Penilaian Sarana Pelatihan

\begin{tabular}{|c|c|c|c|c|c|c|c|}
\hline \multirow{2}{*}{ Indikator } & \multicolumn{5}{|c|}{ Penilaian } & \multirow[t]{2}{*}{ Total } & \multirow{2}{*}{$\begin{array}{l}\text { Rata- } \\
\text { Rata }\end{array}$} \\
\hline & 1 & 2 & 3 & 4 & 5 & & \\
\hline Kenyamanan Ruangan & 0 & 5 & 14 & 11 & 10 & 146 & 3.7 \\
\hline Kualitas media pelatihan & 2 & 1 & 10 & 8 & 19 & 161 & 4.0 \\
\hline Ketersediaan materi pembelajaran & 0 & 2 & 5 & 15 & 18 & 169 & 4.2 \\
\hline Ketersediaan pelatihan lainnya & 0 & 2 & 11 & 11 & 17 & 161 & 4.0 \\
\hline $\begin{array}{l}\text { Ketersediaan sarana pembelajaran } \\
\text { (makan, minum, prokes, atk) }\end{array}$ & 2 & 1 & 3 & 9 & 25 & 171 & 4.3 \\
\hline \multicolumn{6}{|c|}{ Rata-Rata Total } & & 4.04 \\
\hline
\end{tabular}

Sumber : data olahan penulis

Dari tabel tersebut dapat disimpulkan bahwa penilaian mengenai sarana pelatihan dapat dikatakan baik dengan rata-rata poin 4.04 dengan perincian ketersediaan sarana pembelajaran mendapatkan poin tertinggi yakni total 171 dengan rata-rata nilai 4.3; selanjutnya diikuti dengan ketersediaan materi pembelajaran dengan nilai 169 dengan rata rata nilai 4.2. Sedangkan untuk kualitas media dan ketersediaan pelatihan lainnya mendapatkan nilai yang sama yakni 169 dengan nilai rata-rata sebesar 4.0; namun untuk kenyamanan ruangan pelatihan mendapat nilai yang lebih rendah yakni 146 dengan nilai rata-rata 3.7. Dalam hal ini sarana pendukung pelatihan pada umumnya memiliki penilaian yang baik dimana panitia menyediakan sarana pembelajaran yang lengkap mulai dari ketersediaan makan, minum dan alat tulis kantor serta penerapan protokol kesehatan yang cukup baik. Namun ada penilaian yang dirasa kurang yakni kenyamanan ruangan pelatihan dimana perlu dimaklumi dengan ketersediaan tempat pelatihan yang terbatas sehingga kenyamanan ruangan bagi tempat pelatihan sedikit terganggu.

Hasil survey untuk penilaian nara sumber/ pemateri para peserta diberi pertanyaan terkait hal berikut :

1. Penguasaan materi

2. Cara penyampaian materi

3. Komunikasi dengan peserta

4. Kreatif memberi contoh

5. Memberi peran bagi peserta

6. memberikan jawaban pertanyaan

7. Pengelolaan waktu 
Dari ketujuh indikator tersebut maka didapatkanlah data sebagai berikut :

Tabel 3 Penilaian Narasumber

\begin{tabular}{|c|c|c|c|c|}
\hline \multirow{2}{*}{ Penilaian } & \multicolumn{3}{|c|}{ Narasumber } & \multirow{2}{*}{ rata rata } \\
\cline { 2 - 4 } & LA & RA & WRR & \\
\hline Penguasaan Materi & 4.6 & 4.6 & 4.5 & 4.5 \\
\hline Cara Penyampaian & 4.6 & 4.4 & 4.5 & 4.5 \\
\hline Komunikasi & 4.5 & 4.3 & 4.4 & 4.4 \\
\hline Kretifitas memberi contoh & 4.5 & 4.3 & 4.4 & 4.4 \\
\hline memberi peran bagi peserta & 4.3 & 4.2 & 4.3 & 4.3 \\
\hline memberi jawaban pertanyaan & 4.5 & 4.4 & 4.4 & 4.4 \\
\hline pengelolaan waktu & 4.3 & 4.5 & 4.5 & 4.4 \\
\hline \multicolumn{2}{|c|}{ Rata-Rata Total } & & $\mathbf{4 . 4}$ \\
\hline
\end{tabular}

Sumber : data olahan penulis

Dari tabel tersebut dapat disimpulkan bahwa penilaian mengenai narasumber dapat dikatakan baik dengan rata-rata poin 4.4 dimana setiap pemateri memiliki penguasaan materi yang sangat baik disampaikan kepada peserta dengan baik sehingga materi dapat diterima dengan baik serta mudah diaplikasikan sehingga peserta merasa puas terhadap para narasumber. Hal ini juga dibuktikan ketika melakukan latihan asessmen lapangan seluruh peserta dapat melakukannya dengan baik.

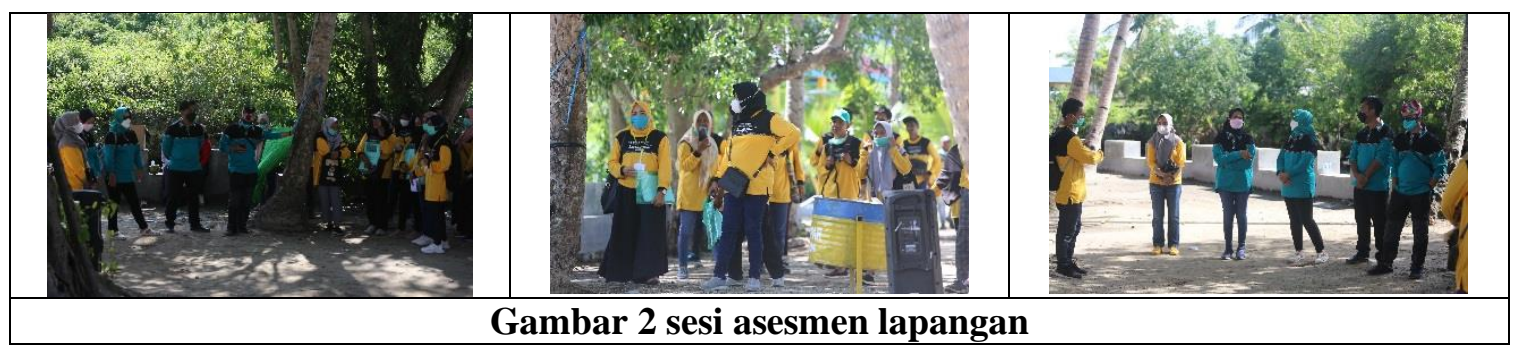

\section{SIMPULAN}

Hasil dari pemberian materi pelatihan pengelolaan desa wisata ini dapat meningkatkan pemahaman bagi para peserta untuk mengelola desa wisata dengan baik. Disini peserta dapat mengaplikasikan materi pelatihan dalam kegiatan latihan asesmen lapangan dengan baik, sehingga mereka dapat kembali mengaplikasikan semua materi yang telah disampaikan di daerahnya masing-masing.

\section{SARAN}

Dari survey yang dilakukan juga terungkap bahwa materi yang telah disampaikan menarik, memberikan wawasan dalam pengelolaan desa wisata dan sesuai dengan kebutuhan di lapangan. Sebagai saran dan masukan dari peserta terkait sarana pendukung pelatihan yang perlu ditingkatkan sehingga kenyamanan peserta pelatihan juga dapat ditingkatkan guna menunjang pelaksanaan pelatihan di kemudian hari.

\section{UCAPAN TERIMA KASIH}

Tim Pelaksana pengabdian masyarakat mengucapkan terima kasih banyak atas kesempatan yang telah diberikan dalam fasilitasi kegiatan ini kepada LPPMJ STIEPAR Yapari Bandung dan LPPM STP Bogor serta Dinas Pariwisata Kabupaten Buton sehingga kegiatan ini dapat terlaksana dengan baik. 


\section{DAFTAR PUSTAKA}

Buku Pedoman Desa Wisata. (2019). Kementrian Pariwisata Republik Indonesia

Busaini, B., Rinuastuti, B., Feriyadin, F., Wijanarko, A., Assidiq, K., Hadinata, L., \& Rahmaningsih, S. (2020). Peran Pemuda dalam Membangun Citra Pariwisata Halal di Desa Setanggor. Jurnal Magister Manajemen, 9(3), 295-304

Djamarah, S., \& Zein, A. (2006). Strategi Belajar Mengajar. Rineka Cipta

Herawati, S., Parantika., Afriza, Lia. (2020). Pelatihan Packaging Produk Unggulan Masayarakat Desa Wisata. Jurnal Masyarakat Mandiri, Vol.4 No. 6, 1040-1048.

Naibaho, R., \& Lubis, Z. (2016). Analisis Peran Pemuda dalam Pembangunan Pariwisata di Kabupaten Serdang Bedagai. Jurnal Ekonom, 19(1), 9-16.

Prabawati, N. (2019). Peran Pemuda dalam Kegiatan Pengembangan Pariwisata di Desa Tibubeneng, Kabupaten Badung, Bali. Jurnal Kepariwisataan Indonesia, 13(1), 73-84.

Prakoso, B.S.E. 2008. The Influence Of Spatial Urbanization To Regional Condition In Periurban Areas Of Yogyakarta. Forum Geografi. Vol. 22. No. 1. pp 27-43.

Soemarno. (2010). Desa Wisata. (http://marno.lecture.ub.ac.id/files/2012/01/Desa-Wisata.doc)

World Tourism Organisation. (2013)

www.butonkab.go.id

Yoeti, O. (2010). Dasar-dasar pengertian hospitality \& pariwisata. Alumni 